\title{
EGFR NM_005228.3:c.2320_2321ins12
}

National Cancer Institute

\section{Source}

National Cancer Institute. EGFR NM 005228.3:C.2320 2321ins12. NCI Thesaurus. Code C98687.

An insertion of 12 nucleotides, GCAACCCCCACG, between position 2320 and 2321 of the coding sequence of the EGFR gene. 